\title{
LIPSTICK EFFECT IN ROMANIA: PROPENSITY TO BUY COSMETICS AND STOCK MARKET EVOLUTIONS
}

\author{
Aurora Murgea ${ }^{1}$
}

\begin{abstract}
Usually, consumer spending declines during recession. Cosmetics seem to disobey this rule; there are evidences to prove that women spending on beauty products increased during the economic turmoil. The scarcity of detailed data regarding this industry makes very hard to test this effect. The present paper tries to overcome the problem, proposing an alternative methodology to analyze if the propensity to buy beauty products, especially lipstick, increased during the last economic crisis. More exactly, we use the normalized number of individuals searching from Romania the world "ruj" (lipstick) on Google as a proxy of aggregate weekly propensity to buy these products and we investigate if BET evolutions (as a proxy for the financial turmoil) are inversely correlated with it. The results drawn from the empirical analysis show the presence of such an inverse correlation on the Romanian market. The decision to buy cosmetics and especially lipstick (a product that instantly change the person imagine and could serve as a rapid mood enhancer) seems to be driven by psychological factors and less by rational ones.
\end{abstract}

Keywords: beauty products, recession, lipstick effect, mood

JEL codes: D01, D12, D53

\section{Introduction}

Lipstick cannot be for sure a panacea for the anxiety of global economic crisis but can serve as a mood enhancer for consumers. The global economic downturn has heavily impacted on the consumer buying behaviour. The reduced financial resources and the increased uncertainty regarding the future determined a serious decrease both in the major purchases as automobiles, homes and luxury items and in the basic purchases as groceries ${ }^{2}$ (Bohlen et.al, 2010; Euromonitor International, 2012). Despite that, because the consumers under pressure still want to feel good and to lift their spirit, the propensity to buy lipstick and other beauty products seems to increase (Schafer, 2008; Alison and Martinez, 2010; Hill et.al, 2012), effect coined in $2008^{3}$ by the head of the cosmetic group Estée Lauder, Leonard Lauder as the „lipstick effect”.

The supporters of this effect find at least two reasonable explanations for its presence: mood enhancing and mating desires.

First, the consumer behaviour is influenced by mood (Holbrook et.al., 2000; Baumeister, 2002) but the relation is bidirectional because the purchase behaviour also impacts on mood. Especially in women case, shopping is perceived as a relaxing or leisure activity and seems to be helpful to overcome the identity problems (Manchanda, 2012). In this way, through hedonic consumption, the consumer simply tries to feel better (Arnold and Reynolds, 2003)

\footnotetext{
${ }^{1}$ West University of Timisoara, Romania, e-mail: aurora.murgea@feaa.uvt.ro

${ }^{2}$ In 2009, the 0,7\% decrease in global real GDP appears to be the most severe downturn from Wall Street Crash of 1929 and the Great Depression. Despite the GDP increase of 5,1\% in the following year, mainly caused by the development in emerging markets, the main part of the worlds developed economies still suffer from an important dip in global demand for consumer goods and services.

${ }^{3}$ Even if the term is relatively new the effect seems to be present long time before someone name it because for instance during the Great recession, cosmetic sales have also increased by $25 \%$.
} 
A newer and unprecedented motivation use ancestral mating psychology to explain why, in a recession time, there is an increased propensity to buy beauty products in women's case (Hill et.al, 2012 ${ }^{4}$ ). When the economic resources are scarce, women are tempted to increase their efforts directed towards attracting mates with resources. Men often chose their romantic partner based on physical attractiveness (Buss and Dedden, 1994; Li et.al., 2002). As an adaptive phenomenon, one of the most efficient methods used by women to attract or retain mates is connected with the increase of physical attractiveness (Sabini and Silver, 2005; Durante et.al, 2011).

The scarcity of reliable historical figures on lipstick and beauty products sales makes hard to clearly demonstrate the lipstick effect. More than that, there are evidences that lipstick sales had grown both in recession and in prosperity periods so it is hard to establish a clear negative correlation (The Economist, 2009).

The purpose of this paper is to investigate, for the first time from our knowledge, the presence of this effect on the Romanian market. Each country due to psychological factors, social influences, and different purchasing power has a different cosmetics purchasing behaviour (Weber and de Villebonne, 2002). That is why, from our point of view, a study focused on only one country could provide more reliable results than a cross-country study. We have chosen Romania due to its particular characteristics. Despite the fact that Romanian women are recognised for their beauty, the average expenses for beauty products is one of the smallest in all Europe ${ }^{5}$ (around 52 Euro/year). This makes Romania an interesting case for a study focused on the presence of the lipstick effect.

The paper is structured as follows: Section 2 presents some of the main actors of beauty product market in Romania and graphically compares their sales evolution with the economy evolution (captured by two opposite variables, Bucharest Stock Exchange Index - BET and the unemployment rate). Section 3 proposes a new approach to investigate the lipstick effect and discusses the main data and methodology. Section 4 examines the relationship between the propensity to buy one of the most sold beauty products in the Romanian cosmetics market, lipstick, and the financial crisis. Section 5 of this paper summarizes the most relevant conclusions.

\section{Romanian beauty product market and economic recession}

Despite the last positive trend in the local producers' turnover evolutions ${ }^{6}$, Romanian beauty product market is still dominated by multinationals as L'Oreal, Beiersdorf, Sarantis and Avon. The value of the beauty and care market estimated by Euromonitor International (2012b) had positive evolutions in the last years but slightly lower than the expected ones, due to the continuation of economic crisis, the VAT increase in mid 2010 and the low household income (978 millions Euro in 2008, 952 millions euro in 2011 and a forecasted 1 billion Euro for 2012).

Analysing the evolutions of the top ten cosmetic distribution companies ${ }^{7}$ in the last 11 years, one could notice that the first positions as sales in 2011 (see Table 1) is occupied by large international companies. On the first position is the largest distribution company in Romania,

\footnotetext{
${ }^{4}$ Hill et.al. (2012), based on five studies, proves the existence of the lipstick effect and state that its presence could be considered as a third indicator of economic recessions, with roots in individual ancestral psychology. In the first study macroeconomic data are used to investigate the relationship between world recession (unemployment is used as proxy in this case ) and consumers habits and behaviours; the second study is designed to experimentally verify the hypothesis that the propensity to buy beauty products in response to an economic decline is driven by women; the third study examines the role of women's preference for financial security in a mate as a mediator in the mechanism of lipstick effect; the fourth study is testing if the price of beauty products influences the lipstick effect and the fifth study enters more deeper, testing which women are more prone to exhibit the lipstick effect

${ }^{5}$ From all the European countries just Turkey encounters smaller values of expenses for beauty products

${ }^{6}$ enhanced during the last year of recession by the shift in the consumer preferences towards cheaper products, with a good quality-price relation

${ }^{7}$ We have chosen to analyse the top ten distribution companies and neglect top ten retailers because the sales of the last category are encapsulated in the first one.
} 
Interbrands Marketing \& Distribution, part of the Lebanese group Sarkis, which managed only in 2011 to recuperate the large decrease in turnover and profits from 2008, 2009 and 2010. On the next positions are very known international companies as Colgate-Palmolive, L'Oreal, Beiersdorf, Sarantis, Johnson and Amway.

In all the cases there are two extremely important drops in the cosmetic sales: one caused by internal problems in 2005, when the Romanian economy has crossed a very important macroeconomic disequilibria and the other in 2008-2009, when the cause was the international economic recession ${ }^{8}$ (see Graph 1 below). The evolutions of the analyzed firms are not necessarily similar. In some of the cases as L'Oreal, Beiersdorf, Johnson, Amway the turnover increased during the crisis but the rhythm severely dropped. In other cases the turnovers severely decreased (for instance in the Interbrands Marketing \& Distribution' case, the decrease in turnover in 2008 was higher than $80 \%$ ).

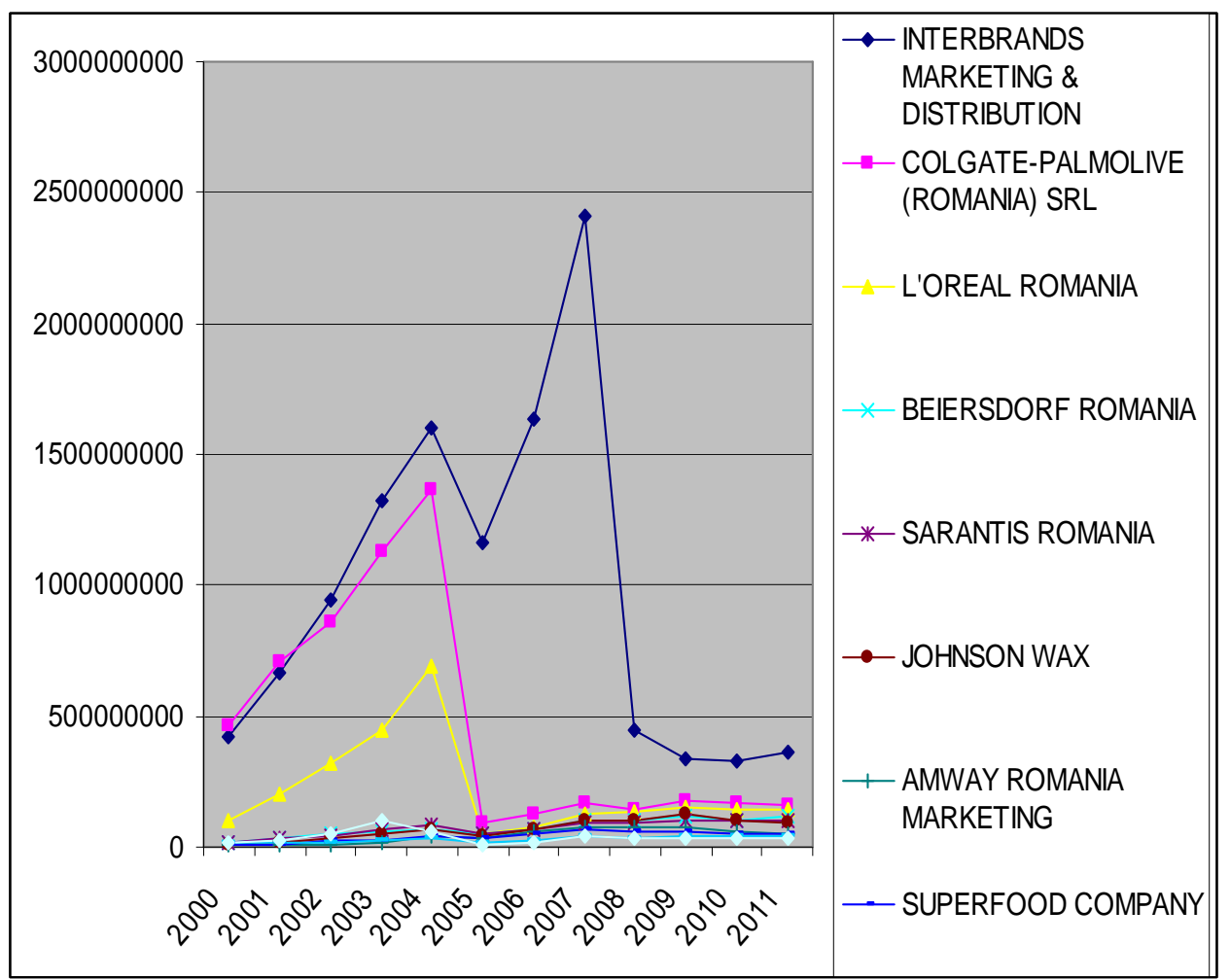

Graph. no. 1 - Inflation adjusted turnovers for top ten cosmetic distribution companies

At the first look, there seems to be no serious evidence of the lipstick effect (see Graph 2), but one cannot neglect the sales increases in the case of the four aforementioned firms. Also, it is still possible that the demand for lipstick or other particular beauty product to be increased in that period but this initial graphic analysis does not allow us to draw any further conclusions regarding the product's particular sales evolutions. A further analyse will be realised in the next paragraph.

\footnotetext{
${ }^{8}$ To represent the economic recession two variables were taken into account: \% change in BET and \% change in unemployment. BET closing values are compiled from Bucharest Stock Exchange website: www.bvb.ro. Unemployment rates are compiled from National Bank of Romania website: www.bnro.ro
} 


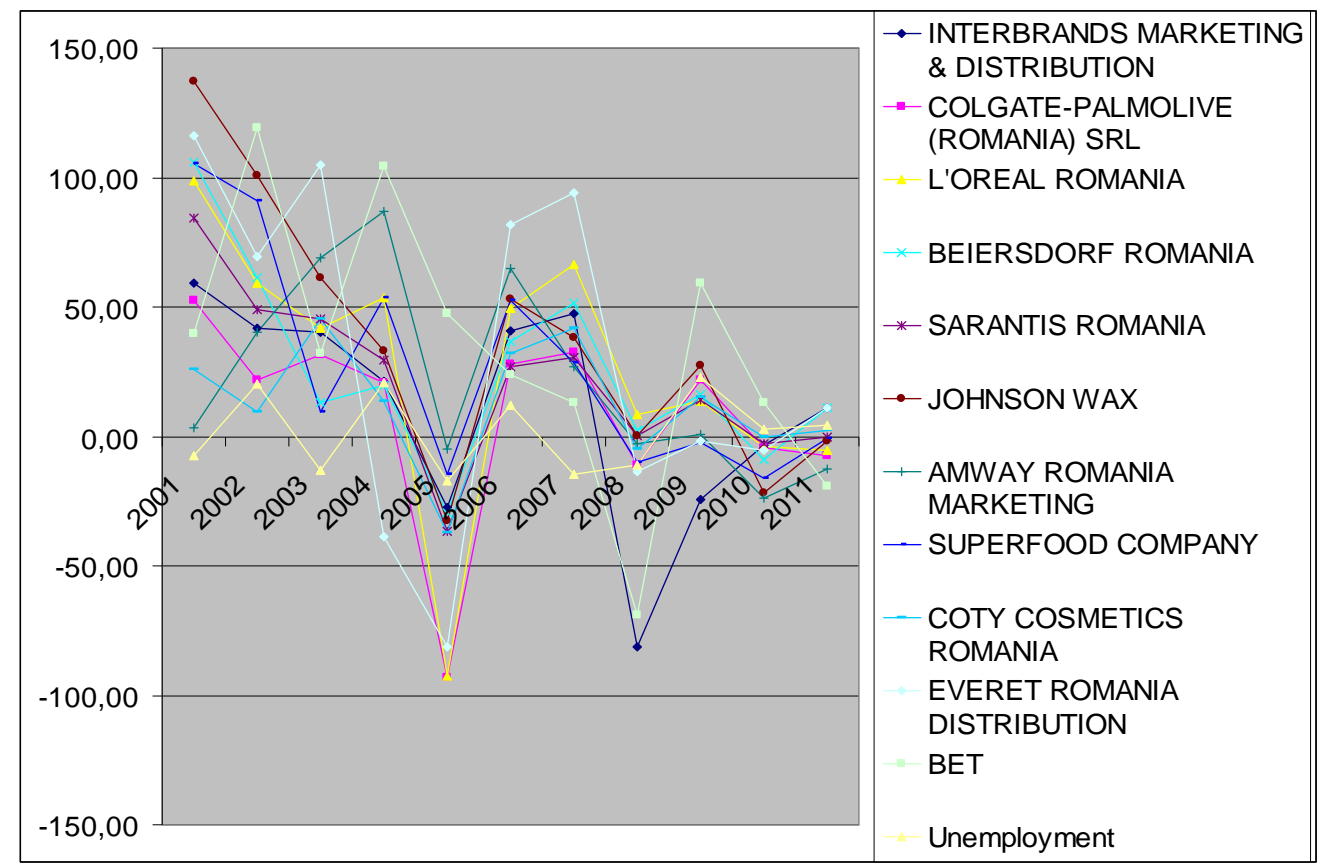

Graph. no. 2. - Top ten distribution companies and economic downturn (\% change in turnover on a year earlier, inflation adjusted)

If we are analysing the segment of cosmetic producers, Romanian producer Farmec gains the lead, at a very big distance from its competitors, with a turnover of more then 25 mil Euro in 2011 compared with around 6 mil for Papillon Laboratoires Cosmetiques (the second position) or almost 2 mil for Gerocossen (the third position). The Farmec success is mainly determined by the Gerovital brand (with very famous trade marks as Gerovital H3 Evolution, Gerovital H3 prof. dr. Ana Aslan, Gerovital Plant) that gained the first position in the beauty and care products among Romanian consumers, as trust and affectivity (Biz and Unlock Market Research, 2012).

Cosmetic producers companies have been less affected by the crisis than the first category (see Graph 3). The autochthon products gain recognition in the last years and the propensity of buying and using these products among Romanians increased (on the one side due to their smaller price compared with alternative foreign products and on the other side due to their high quality).

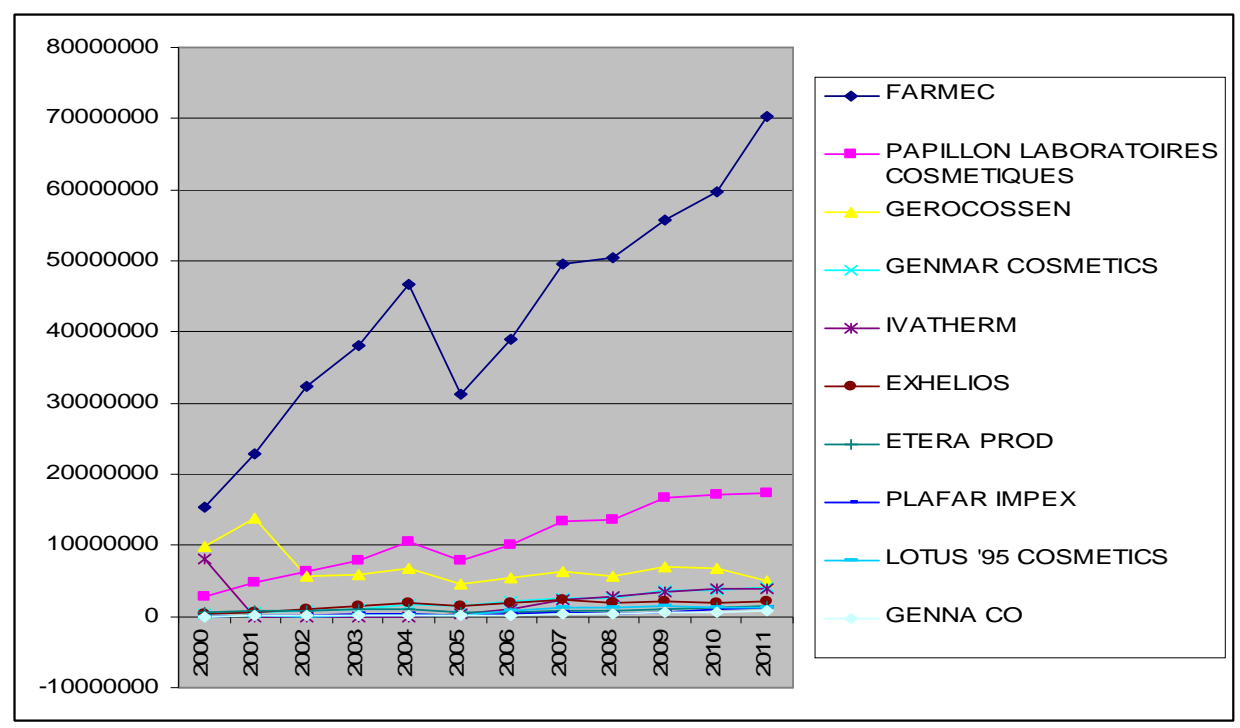

Graph. no. 3 - Inflation adjusted turnovers for top ten cosmetic production companies 
Looking more attentive at the evolutions during the crisis (see Table 2 and Graph 4), one could see that just in two cases, Gerocossen and Exhelios there were serious turnover decreases. In the rest of the cases, the tendency was to continue the increase tendency, even if with smaller percentages due to the economic downturn (Farmec, Papillon Laboratoires Cosmetiques, Ivatherm, Lotus'95 Cosmetics).

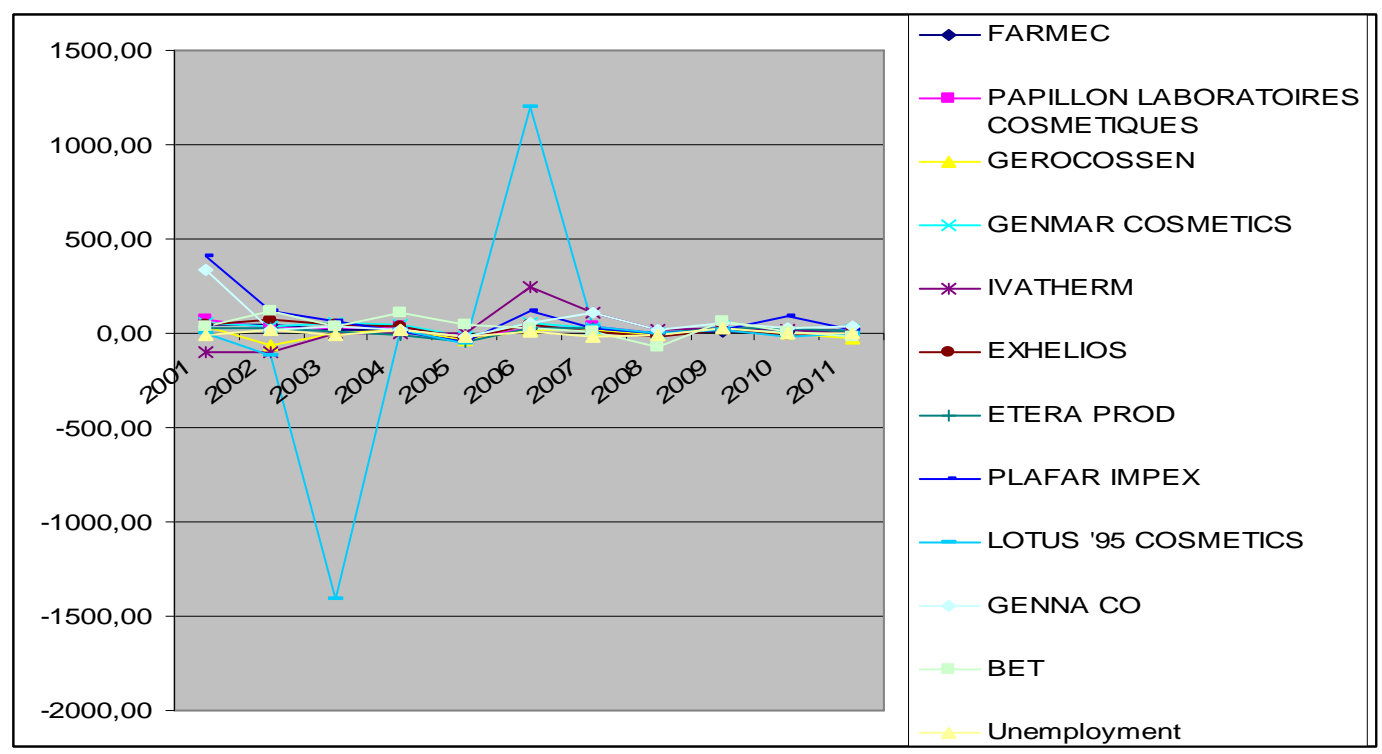

Graph no. 4. - Top ten cosmetic producers and economic downturn

(\% change in turnover on a year earlier, inflation adjusted)

In direct sales segment, three international companies are by far the market leaders: Avon Cosmetics Romania, Cosmetics Oriflame Romania and FM Group Cosmetics Romania. All three have had pretty constant evolutions before and after the crisis with no very important picks ${ }^{9}$. The financial crisis did not generate either severe drops in sales or important increases (see Graph 5).

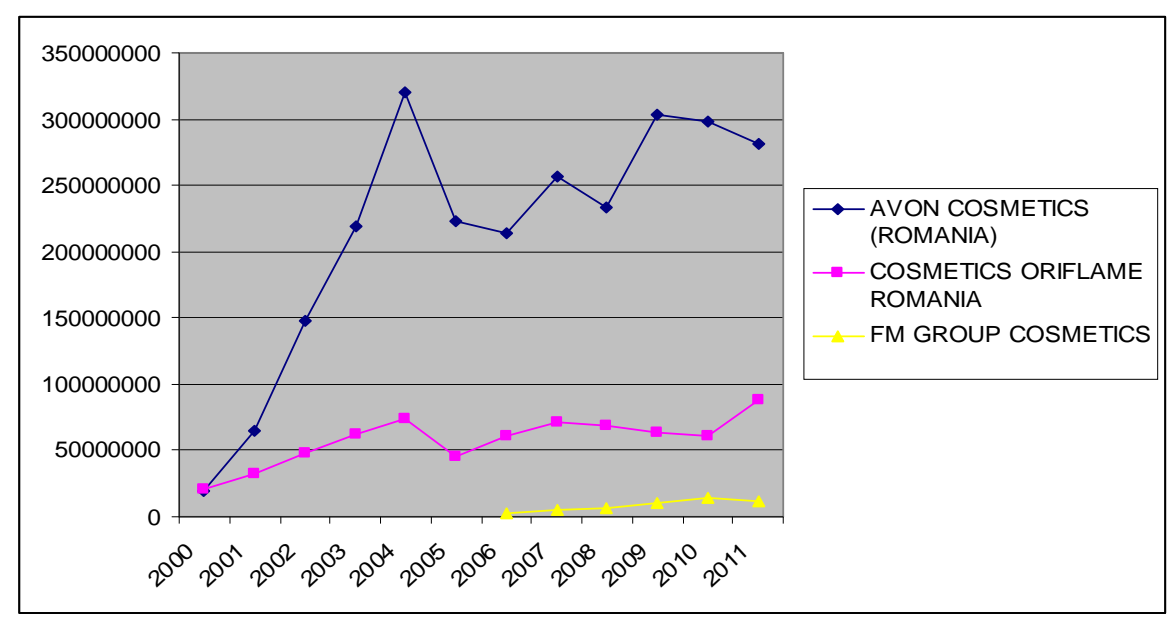

Graph. no. 5. - Inflation adjusted turnovers for top direct sales cosmetic companies

\footnotetext{
${ }^{9}$ The sales of Avon Cosmetic had a small decrease in 2008 due to internal scandals caused by the bribe accuses in top management level of the company.
} 
Despite the fact that cosmetic products gained the lead in the Romanian direct sales (almost $80 \%$ of the market) the Romanians interest for them decreased in the last years because more and more individuals prefer to buy this kind of products from the retailers, where the diversity of products and the buying process could bring supplementary advantages.Analyzing those figures compared with the economic downturn (Graph 6 and Table 3) the conclusion holds: the economical crisis do not change much the evolution of sales, neither the preference for their products.

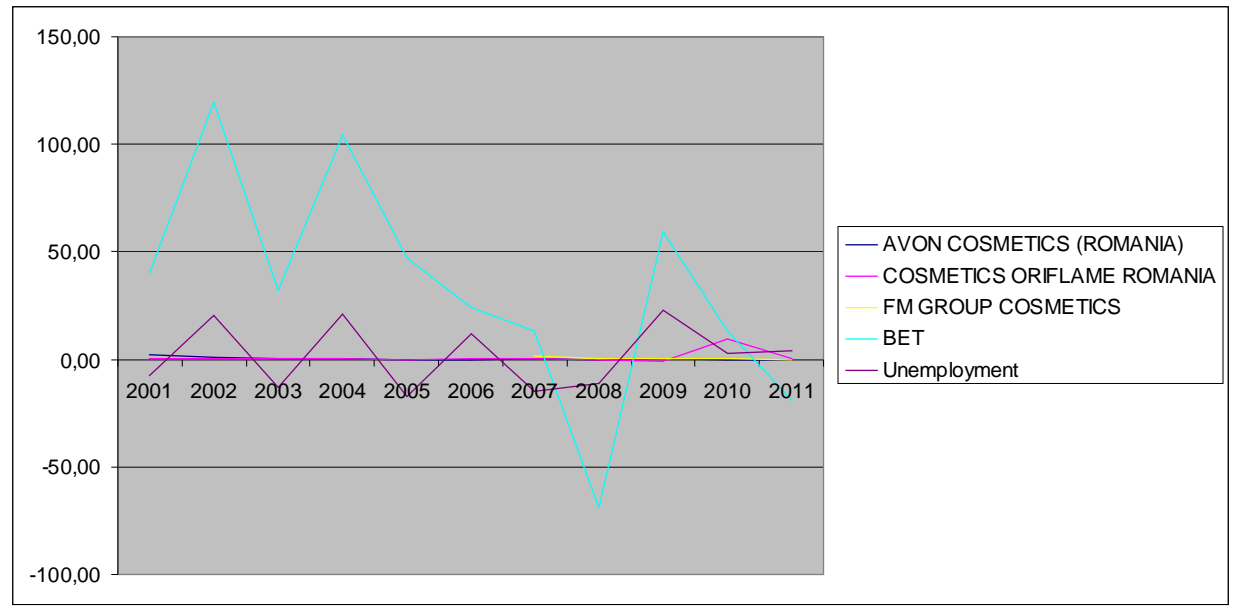

Graph. no. 6. - Top cosmetic companies in top 20 of the best direct sales companies and economic downturn

\section{Is there any lipstick effect on Romanian market?}

Based on the overview we had realised, one could conclude that the sales in the cosmetic market in Romania were not extremely affected by the crisis but, in the same time, it is hard to prove that the crisis increased the Romanian preference for cosmetics, especially for lipstick, as the lipstick effect hypothesises.

In order to realise a more reliable analysis one would need the exact value of the sales, on each product, for the entire industry. Because these kind of data is hardly available we are proposing as a proxy for the propensity of buying lipstick, the normalized number of individuals searching on Google the words " $r u j$ " (lipstick in Romanian) from Romanian web addresses ( the idea of using this kind of proxy came from a paper wrote in 2012 by Becchetti et.al., who uses the normalized number of individuals searching on Google the word "felicità" - happiness in Italianfrom Italian web addresses and "glück" - happiness in German- from German web addresses, in order to build a high frequency indicator of life satisfaction). People searching for the word "ruj" have a desire to buy this product so, the number of individuals searching for this word could be used as a measure for the propensity to buy it in that period. Usually individuals are searching for things because they do not have them otherwise they would not pay the cost of looking for information (for similar conclusions see the behaviour of web surfers looking for information about illnesses they have or could have in: Brodie et al., 2000; Dickerson et al., 2004; Ybarra and Suman, 2006).

\section{Data and descriptive statistics}

Our empirical analysis aims to test the relation between the propensity to buy certain types of cosmetics, measured by the number of individuals searching for the word "ruj" form Romanian web addresses, and the economic downturn measured by the values of Bucharest Stock Exchange Index. The analysis uses weekly time series starting from 06.07.2008 to 23.06.2012. 
The number of individuals searching for the word "ruj" on Google is taken from the Google "Insights for search", statistics which automatically normalize ${ }^{10}$ on a 0-100 scale the information in the selected interval. The Google week interval goes from Monday until Sunday (and therefore is not influenced by the following week market opening) ${ }^{11}$. The closing values of BET are downloaded from Bucharest Exchange web-site.

Because the proposed analysis is a dynamic one and we are interested if the propensity to buy this product increases or decreases during the crisis period, we are using dynamic growth rates instead of raw data. Their main descriptive statistics are presented in the Table no. 4.

Table no. 4

\section{Descriptive statistics}

\begin{tabular}{lcc}
\hline \multicolumn{1}{c}{ Statistics } & DGR_SEARCH_RUJ & DGR_CLOSE_BET \\
Mean & 0.002553 & 0.002184 \\
Median & 0.017700 & 0.003522 \\
Maximum & 0.644357 & 0.084222 \\
Minimum & -0.929536 & -0.154484 \\
Std. Dev. & 0.266789 & 0.036335 \\
Skewness & -0.573164 & -0.767904 \\
Kurtosis & 4.032704 & 5.607763 \\
& & 53.80993 \\
Jarque-Bera & 13.98570 & 0.000000 \\
Probability & 0.000918 & 0.307888 \\
Sum & & 0.184837 \\
Sum Sq. Dev. & 0.359984 & 141 \\
Observations & 9.964669 & \\
\hline
\end{tabular}

where:

DGR_SEARCH_RUJ - dynamic growth rate of the number of searches of the word "ruj" on the Google from Romanian addresses: $D R G_{-}$SEARCH_RUI $t=\ln \left(\frac{\text { SEARCH_RUJ }}{\text { SEARCH_RUI }}\right)$

DGR_Close_BET-dynamic growth rate of the BET close value computed using closing Friday values of the indexDRG_CLOSE_BET $=\ln \left(\frac{\text { CLOSE_EET }_{t}}{\text { CLOSE_BET }_{t-1}}\right)$

Both dynamic growth series have been checked for unit root using Augmented DickeyFuller, Dickey-Fuller GLS and Philips-Perron tests (including also intercept, trend and intercept). We were able to reject the null and concluded that both series are stationary (the t-statistic values were inferior to the critical values at $1 \%, 5 \%$ and $10 \%$ levels, with a p-value of 0.0000 ).

\section{Model, specification and result}

The main hypothesis we are trying to verify is the existence of a negative correlation between stock market evolutions (as a proxy for the economic downturn) and the propensity to buy lipstick on the Romanian cosmetic market (see in the Graph 6 the scatter plot that connect these two variables; at the first look the variables seems to have a linear relationship).

\footnotetext{
${ }^{10}$ The available data are the weekly number of web searches normalized with respect to the week of maximum search contained on our time interval which is conventionally set at 100 . Details on the reliability of the information and the methodology adopted can be found in the web page http://www.google.com/trends/correlate.

${ }^{11}$ Our use of the Friday market close reflects the fact that individuals have more time to search on the web in the weekend and therefore this value is expected to influence strongly the weekly Google search values measured till Sunday.
} 


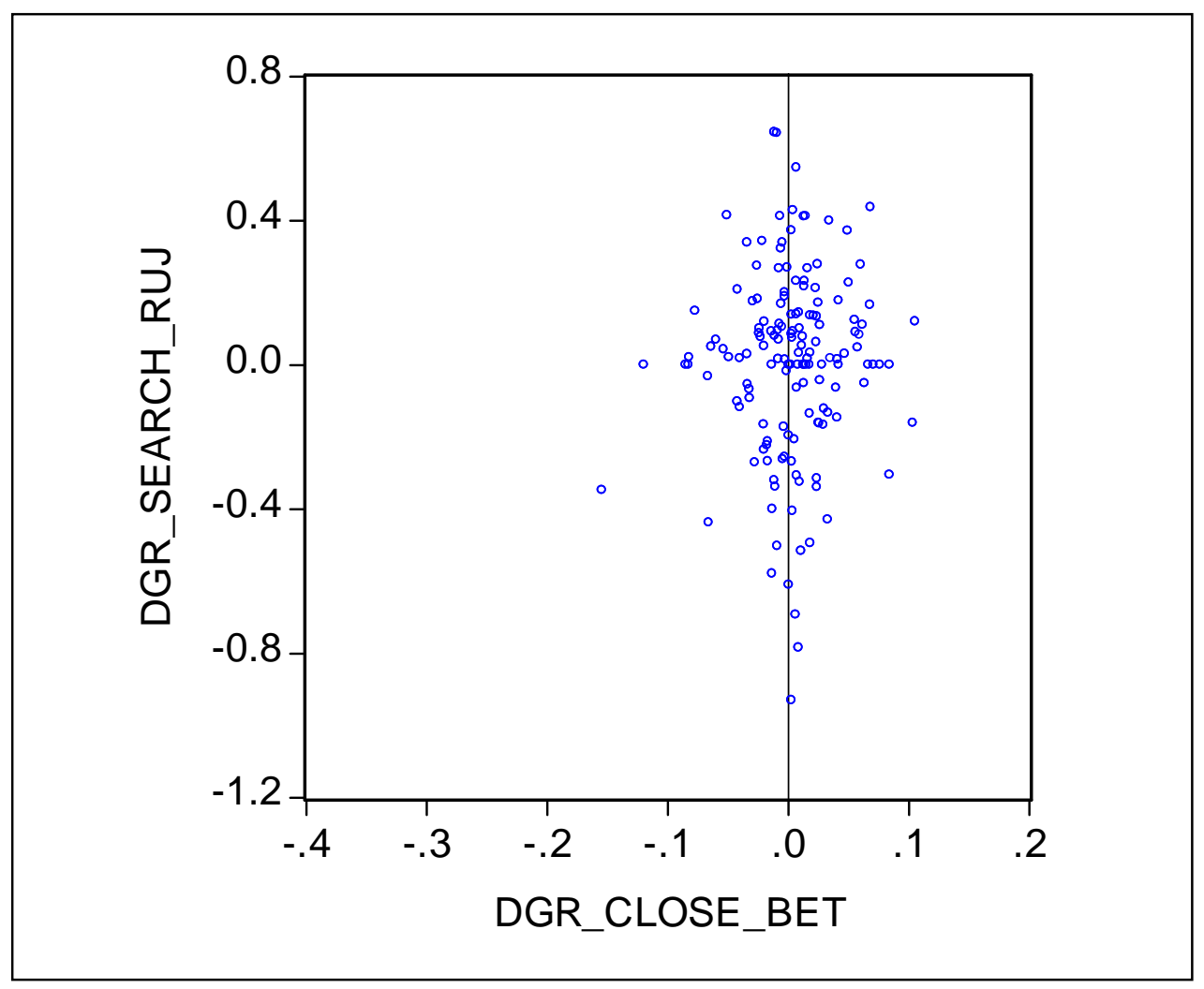

Graph. no. 6. - Variables dynamic in time

In order to investigate if we can confirm the lipstick effect we are using a VAR model. Due to particular nature of the variables - both variables could be considered dependent by their previous values and in the same time both could represent an explanatory variable for the other- a VAR model could lead to better results than a simple OSL estimation. For instance economic downturn could impact on the propensity of buying lipstick either in the direction of reducing it, as a result of income reduction, either in the direction explained by the lipstick effect. In the same time, through the channel of mood enhancing, the propensity to buy beauty product cold also influence the risk aversion attitude and the market evolutions (for further details regarding the mood influence in financial decision see Affect Infusion Model proposed by Forgas in 1995 and Mood Maintenance Hypothesis proposed by Isen et.al. in 1998).

Based on lag exclusion test we have chosen a VAR model with 1 lag, with the following general form:

$$
\left\{\begin{array}{l}
D G R_{-} S E A R C H_{-} R U J=a_{1_{1}} D R G_{-} S E A R C H_{-} R U J_{t-1}+a_{1_{2}} D G R_{-} C L O S E_{-} B E T_{t-1}+b_{1} \\
D G R_{-} C L O S E_{-} B E T=a_{2_{1}} D G R_{-} S E A R C H_{-} R U J_{t-1}+a_{2_{2}} D G R_{-} C L O S E_{-} B E T_{t-1}+b_{2}
\end{array}\right\}
$$

that leaded to the results presented in the Table 5. 
Table no. 5 .

The results from VAR model

Included observations: 148 after adjustments

Standard errors in ( ) \& t-statistics in [ ]

\begin{tabular}{|c|c|c|}
\hline & DGR_SEARCH_RUJ & $\begin{array}{c}\text { DGR_CLOSE_BE } \\
\mathrm{T}\end{array}$ \\
\hline \multirow{3}{*}{ DGR_SEARCH_RUJ(-1) } & -0.450372 & -0.000318 \\
\hline & $(0.07321)$ & $(0.01235)$ \\
\hline & {$[-6.15172]$} & {$[-0.02573]$} \\
\hline \multirow[t]{3}{*}{ DGR_CLOSE_BET(-1) } & -0.783142 & 0.051397 \\
\hline & $(0.49089)$ & $(0.08283)$ \\
\hline & {$[-1.59534]$} & {$[0.62055]$} \\
\hline \multirow[t]{3}{*}{$\mathrm{C}$} & 0.003779 & 0.002805 \\
\hline & $(0.01914)$ & $(0.00323)$ \\
\hline & {$[0.19740]$} & {$[0.86850]$} \\
\hline R-squared & 0.222961 & 0.002649 \\
\hline Adj. R-squared & 0.212243 & -0.011107 \\
\hline Sum sq. resids & 7.816003 & 0.222504 \\
\hline S.E. equation & 0.232171 & 0.039173 \\
\hline F-statistic & 20.80288 & 0.192579 \\
\hline Log likelihood & 7.633990 & 270.9988 \\
\hline Akaike AIC & -0.062621 & -3.621605 \\
\hline Schwarz SC & -0.001867 & -3.560851 \\
\hline Mean dependent & 0.000887 & 0.002960 \\
\hline S.D. dependent & 0.261585 & 0.038957 \\
\hline \multicolumn{2}{|c|}{ Determinant resid covariance (dof adj.) } & 8.23E-05 \\
\hline \multicolumn{2}{|c|}{ Determinant resid covariance } & $7.90 \mathrm{E}-05$ \\
\hline \multicolumn{2}{|c|}{ Log likelihood } & 279.0217 \\
\hline \multicolumn{2}{|l|}{ Akaike information criterion } & -3.689483 \\
\hline \multicolumn{2}{|l|}{ Schwarz criterion } & -3.567974 \\
\hline
\end{tabular}

The model was tested for stability and there are no roots lying outside the unit circle. The robustness was checked through VAR residual Portmanteau test for autocorrelation, VAR residual serial correlation LM and VAR residual Heteroskedasticity Test. All the results show that the VAR model with 1 lag is a robust and stable one.

As one could see in Graph 7, an impulse in BET seems to generate a short term, strong inverse response in propensity to buy lipstick that confirms the suppositions of the lipstick effect theory $^{12}$.

\footnotetext{
${ }^{12}$ Same conclusion could be drawn also if one looks at the estimated VAR model coeficients:

DGR_SEARCH_RUJ $=-0.450372283 *$ DGR_SEARCH_RUJ(-1) $-0.783142361 *$ DGR_CLOSE_BET(-1) + 0.003778518099

DGR_CLOSE_BET $=-0.0003178717314 *$ DGR_SEARCH_RUJ $(-1)+0.05139736094 *$ DGR_CLOSE_BET $(-1)+0.002804925478$
} 


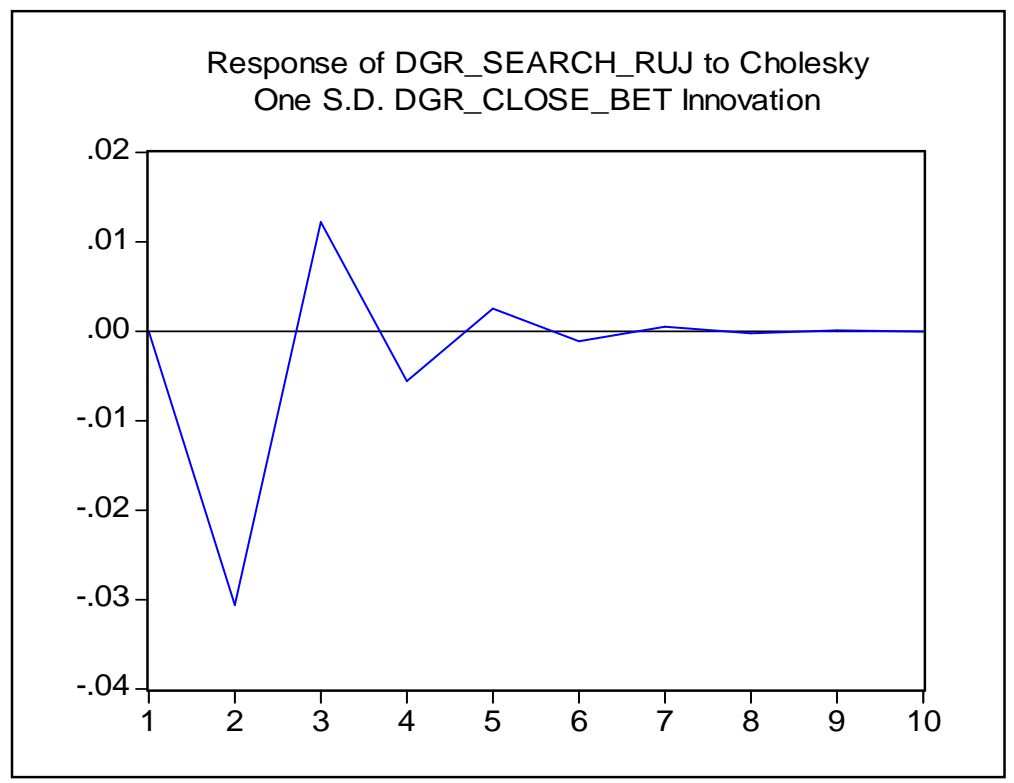

\section{Graph. no. 7. - The effect of an impulse generated by the capital market evolutions on the propensity to buy lipstick}

On the other side, seems that from the two alternative aforementioned theories regarding the relation between mood and capital market, our model confirms Mood Maintenance Hypothesis ${ }^{13}$ for an extremely short moment in time. After that, the system quickly stabilises (see Graph 8). The former BET evolutions have an importantly larger effect on its present values, as one can easily see from the model coefficients, so the mood change impact quickly disappears.

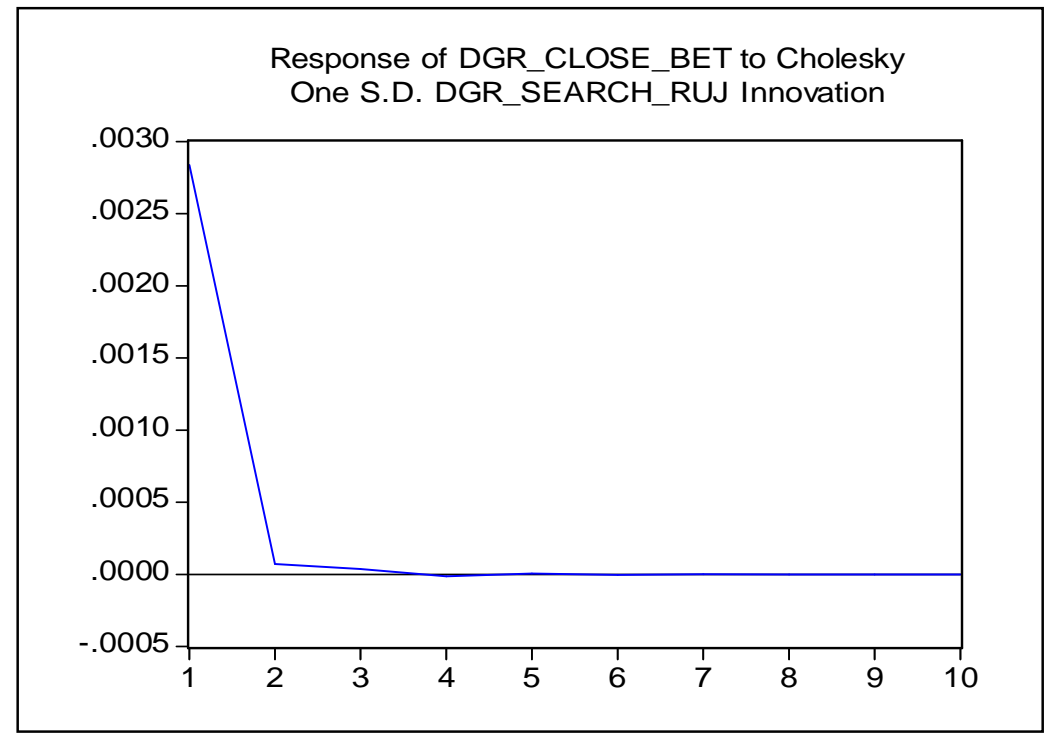

Graph. no. 8. - The effect of an impulse generated by the propensity to buy lipstick on the capital market evolutions

\footnotetext{
${ }^{13}$ A better mood induced by a larger propensity to buy lipstick seems to increase the risk aversion and reduces the capital market growth
} 


\section{Conclusions}

Motivations that drive consumer spending are clearly not always intuitive or rational. Our analysis showed an increase in the sales of an important part of the companies that produce or distribute cosmetic on the Romanian market, despite the crisis.

More than that, the propensity to buy lipstick seems to be inversely correlated with the capital market evolution. This conclusion allows us to consider that in fact the motivation that stays behind the decision to buy cosmetics and especially lipstick (a product that instantly change the person imagine and could serve as a rapid mood enhancer) is driven by psychological factors and less by rational ones as the level of incomes. Our study does not go further to asses what kind of psychological motivations support this propensity, mood enhancing or the mating desires but it offers empirical proves that lipstick effect do exist on the Romanian market. A future study could extend its findings and test also for the psychological motivation that determines the presence of this effect on the Romanian market.

Despite the fact that this was not the main purpose of the study, this analysis could be also helpful as a starting point for a further investigation of the effect of mood on the capital market evolutions. The results of the VAR model offer support for the idea that individuals with a better mood could have a higher risk aversion, generated by the desire to maintain this state of mind and this could be transposed in lower demand for stocks and lower returns of the capital markets. Some different mood enhancers could be used in order to test this hypothesis on the Romanian capital market.

\section{References}

1. Allison M., Martinez A., 2010. Beauty-products sales bright spot during recession, The Seattle Times, Retrieved from http://seattletimes.com at $12^{\text {th }}$ September 2012.

2. Arnolds M., Reynolds K.E., 2003. Hedonic Shopping, Journal of Retailing, 79(2):77-95.

3. Baumeister R., 2002, Yielding to Temptation: Self-Control Failure, Impulse Purchasing, and Consumer Behavior, Journal of Consumer Research, 28 (4), pp. 670-676.

4. Becchetti L., Marini G., Murgea A., 2012. The Spread Nightmare: Financial Crises and Happiness, CEIS Working Paper No. 252. Available at SSRN: http://ssrn.com/abstract=2148345

5. Biz and Unlock Market Research, 2012. 50 dintre cele mai puternice branduri romanesti, Bucuresti, Biz

6. Bohlen B., Carlotti S., Mihas L., 2010. How the recession has changed US consumer behaviour, McKinsey Quarterly, 1, pp. 17-20

7. Brodie M., Flournoy R.E., Altman D.E, Blendon R.J., Benson J.M., Rosenbaum M.D., 2000. Health information, the Internet, and the digital divide, Health Affairs, 19(6), pp. 255-265

8. Buss D. M., Dedden L. A., 1990. Unmitigated agency and unmitigated communion: An analysis of the negative components of masculinity and femininity, Sex Roles, 22, pp. 555568

9. Dickerson S., Reinhart A.M., Feeley T.H., Bidani R., Rich E., Garg V.K., O Hershey C.O., 2004. Patient Internet use for health information at three urban primary care clinics, Journal of the American Medical Informatics Association, 11, pp. 499-504.

10. Durante K. M., Griskevicius V., Hill S. E., Perilloux C., Li N. P., 2011. Ovulation, female competition, and product choice: Hormonal influences on consumer behaviour, Journal of Consumer Research, 37, pp. 921-934.

11. Forgas J.P., 1995. Mood and judgement: the affect infusion model (AIM), Psychological Bulletin 117, pp. 39-66

12. Hill S.E., Rodeheffer C.D., Griskevicius V., Durante K., White A.E., 2012. Boosting Beauty in an economic decline: mating, spending, and the lipstick effect, Journal of Personality and Social Psychology, 103(2), pp. 275-291 
13. Holbrook M. B., Gardner M. P., 2000. Illustrating a dynamic model of the mood-updating process in consumer behavior, Psychology \& Marketing, 17(3), pp. 165-194.

14. Isen A.M., Nygren T.E., Ashby F.G., 1998. Influence of positive affect on the subjective utility of gains and losses: it is just not worth the risk, Journal of Personality and Social Psychology, 55, pp. 710-717

15. Euromonitor International, 2012a. Consumer buying behaviour in the recession: global online Survey, Retrieved from http://www.euromonitor.com/consumer-buying-behaviour-inthe-recession-global-online-survey/report at $12^{\text {th }}$ September 2012.

16. Euromonitor International, 2012b. Beauty and Personal care in Romania, Retrieved from http://www.euromonitor.com/beauty-and-personal-care-in-romania/report at $8^{\text {th }}$ October 2012.

17. Li N. P., Bailey J. M., Kenrick D. T., Linsenmeier J. A. W., 2002. The necessities and luxuries of mate preferences: Testing the tradeoffs, Journal of Personality and Social Psychology, 82, pp. 947-955.

18. Manchanda R., 2012. A comparative study of compulsive buying behaviour between working and non-working women, Pragyaan: Journal of Management, 10(1), pp.1-9

19. Sabini J., Silver M., 2005. Gender and jealousy: Stories of infidelity, Cognition \& Emotion, 19, pp. 713-727

20 Schaefer K., 2008. Hard times, but your lips look great, The New York Times, Retrieved from http://www.nytimes.com/2008/05/01/ fashion/01SKIN.html?pagewanted_all at $2^{\text {nd }}$ October 2012

21. The Economist, 2009. Lip reading, Retrieved from http://www.economist.com/node/12995765 at $6^{\text {th }}$ November 2012

22. Weber J.M., de Villebonne J.C., 2002. Differences in purchase behavior between France and the USA: the cosmetic industry, Journal of Fashion Marketing and Management, 6(4), pp. $396-407$

23. Ybarra M.L., Suman M., 2006. Help seeking behavior and the Internet: a national survey, International Journal of Medical Informatics, 75, pp. 29-41 


\section{Appendix}

Table no. 1.

Top ten distribution companies (\% change in turnover on a year earlier, inflation adjusted)

\begin{tabular}{|c|c|c|c|c|c|c|c|c|c|c|c|c|}
\hline No. & COMPANIES & 2001 & 2002 & 2003 & 2004 & 2005 & 2006 & 2007 & 2008 & 2009 & 2010 & 2011 \\
\hline 1 & $\begin{array}{l}\text { INTERBRANDS } \\
\text { MARKETING \& } \\
\text { DISTRIBUTION }\end{array}$ & 59,18 & 41,60 & 40,20 & 21,18 & $-27,56$ & 40,84 & 47,67 & $-81,44$ & $-24,40$ & $-3,19$ & 11,26 \\
\hline 2 & $\begin{array}{l}\text { COLGATE- } \\
\text { PALMOLIVE } \\
\text { (ROMANIA) SRL }\end{array}$ & 52,69 & 21,94 & 31,31 & 20,56 & $-92,88$ & 27,98 & 32,66 & $-11,12$ & 21,99 & $-4,43$ & $-7,61$ \\
\hline 3 & L'OREAL ROMANIA & 98,85 & 59,33 & 41,67 & 53,59 & $-92,79$ & 49,63 & 66,19 & 8,36 & 13,80 & $-3,85$ & $-5,22$ \\
\hline 4 & $\begin{array}{l}\text { BEIERSDORF } \\
\text { ROMANIA }\end{array}$ & 105,96 & 61,11 & 13,10 & 19,69 & $-29,53$ & 36,86 & 51,74 & 2,06 & 15,93 & $-8,76$ & 11,14 \\
\hline 5 & SARANTIS ROMANIA & 84,16 & 48,86 & 45,40 & 29,63 & $-36,69$ & 26,79 & 30,48 & 0,25 & 14,31 & $-2,92$ & $-0,18$ \\
\hline 6 & JOHNSON WAX & 137,09 & 100,71 & 61,04 & 33,13 & $-32,50$ & 53,18 & 38,37 & 0,40 & 27,54 & $-21,74$ & $-1,94$ \\
\hline 7 & $\begin{array}{l}\text { AMWAY ROMANIA } \\
\text { MARKETING }\end{array}$ & 3,14 & 40,26 & 69,04 & 86,96 & $-4,93$ & 64,73 & 26,78 & $-3,05$ & 0,67 & $-24,10$ & $-12,53$ \\
\hline 8 & $\begin{array}{l}\text { SUPERFOOD } \\
\text { COMPANY }\end{array}$ & 105,53 & 90,88 & 9,38 & 53,49 & $-14,83$ & 52,47 & 28,71 & $-9,79$ & $-2,42$ & $-16,07$ & $-0,78$ \\
\hline 9 & $\begin{array}{l}\text { COTY COSMETICS } \\
\text { ROMANIA }\end{array}$ & 25,84 & 9,32 & 45,52 & 13,55 & $-37,24$ & 32,10 & 41,64 & $-4,84$ & 15,08 & $-0,04$ & 2,54 \\
\hline 10 & $\begin{array}{l}\text { EVERET ROMANIA } \\
\text { DISTRIBUTION }\end{array}$ & 116,14 & 69,50 & 104,72 & $-38,84$ & $-81,43$ & 81,61 & 94,13 & $-13,53$ & $-1,57$ & $-5,44$ & 10,93 \\
\hline
\end{tabular}

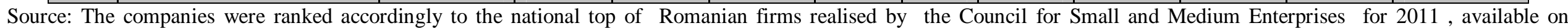
http://top.cnipmmr.ro/clasamente.html

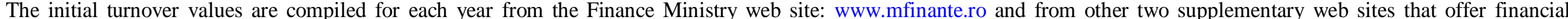

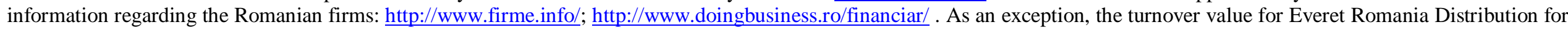
2004 is an estimated value.

Inflation rates were compiled from the National Bank of Romania website : $\underline{w w w . b n r o . r o}$ 
Top ten cosmetic producers (\% change in turnover on a year earlier, inflation adjusted)

Table no. 2.

\begin{tabular}{|c|c|c|c|c|c|c|c|c|c|c|c|c|}
\hline No. & COMPANIES & 2001 & 2002 & 2003 & 2004 & 2005 & 2006 & 2007 & 2008 & 2009 & 2010 & 2011 \\
\hline 1 & FARMEC & 49,14 & 41,08 & 17,90 & 22,45 & $-33,11$ & 24,79 & 27,18 & 1,41 & 10,64 & 7,06 & 17,79 \\
\hline 2 & $\begin{array}{l}\text { PAPILLON } \\
\text { LABORATOIRES } \\
\text { COSMETIQUES }\end{array}$ & 76,31 & 30,77 & 23,08 & 35,64 & $-26,14$ & 27,68 & 34,03 & 1,30 & 22,79 & 2,84 & 1,62 \\
\hline 3 & GEROCOSSEN & 40,83 & $-59,34$ & 2,48 & 17,29 & $-33,93$ & 21,16 & 18,18 & $-12,81$ & 25,95 & $-4,31$ & $-26,16$ \\
\hline 4 & GENMAR COSMETICS & 57,03 & 32,75 & 51,89 & 45,10 & $-13,72$ & 54,04 & 24,74 & $-3,67$ & 38,58 & 3,48 & 14,10 \\
\hline 5 & IVATHERM & $-99,96$ & $-100,00$ & 0,00 & 0,00 & 0,00 & 249,43 & 109,49 & 19,60 & 25,15 & 15,92 & $-0,15$ \\
\hline 6 & EXHELIOS & 48,85 & 76,97 & 48,29 & 37,66 & $-29,62$ & 46,14 & 13,50 & $-14,09$ & 14,50 & $-10,64$ & 3,65 \\
\hline 7 & ETERA PROD & 26,95 & 30,66 & 11,79 & $-6,17$ & $-49,30$ & 26,91 & 29,38 & $-0,48$ & 23,14 & 24,64 & 11,55 \\
\hline 8 & PLAFAR IMPEX & 411,80 & 116,14 & 60,69 & 9,89 & $-48,27$ & 117,85 & 26,80 & $-2,57$ & 20,91 & 91,01 & 21,89 \\
\hline 9 & LOTUS '95 COSMETICS & 0,00 & $-114,67$ & $-1406,03$ & 21,65 & $-51,43$ & 1195,65 & 40,19 & 3,45 & 16,72 & $-16,91$ & 1,23 \\
\hline 10 & GENNA CO & 337,17 & 15,09 & 39,41 & 15,84 & $-18,45$ & 53,25 & 106,09 & 16,07 & 58,96 & 24,24 & 35,35 \\
\hline
\end{tabular}

Source: similar with the ones from Table 1. The exception in this case is Gerocossen's turnover in 2001 and 2009, for which the values are estimated using the past trend.

Table. no. 3 .

Top cosmetic companies in top 20 of the best direct sales companies (\% change in turnover on a year earlier, inflation adjusted)

\begin{tabular}{|c|c|c|c|c|c|c|c|c|c|c|c|c|}
\hline No. & COMPANIES & 2001 & 2002 & 2003 & 2004 & 2005 & 2006 & 2007 & 2008 & 2009 & 2010 & 2011 \\
\hline 1 & $\begin{array}{l}\text { AVON COSMETICS } \\
\text { (ROMANIA) }\end{array}$ & 2,34 & 1,27 & 0,49 & 0,46 & $-0,30$ & $-0,04$ & 0,20 & $-0,09$ & 0,30 & $-0,02$ & $-0,06$ \\
\hline 2 & $\begin{array}{l}\text { COSMETICS ORIFLAME } \\
\text { ROMANIA }\end{array}$ & 0,62 & 0,46 & 0,31 & 0,17 & $-0,38$ & 0,34 & 0,18 & $-0,04$ & $-0,08$ & $-0,04$ & 0,45 \\
\hline 3 & FM GROUP COSMETICS & & & & & & & 1,28 & 0,14 & 0,61 & 0,37 & $-0,17$ \\
\hline
\end{tabular}

Source: similar with the ones from Table 1 